\title{
Effect of neonatal and adult testosterone treatment on the cellular composition of the adult female rat anterior pituitary
}

\author{
S González-Parra ${ }^{1}$, J Argente ${ }^{1,2}$, L M García-Segura ${ }^{3}$ and \\ J A Chowen ${ }^{2,3}$ \\ ${ }^{1}$ Universidad Autónoma, Department of Pediatrics, Hospital Infantil del Niño Jesús, Avenida Menéndez y Pelayo 65, 28009 Madrid, Spain \\ ${ }^{2}$ Unit of Investigation, Hospital Infantil del Niño Jesús, Avenida Menéndez y Pelayo 65, 28009 Madrid, Spain \\ ${ }^{3}$ Instituto Cajal, CSIC, Avenida Dr Arce 37, 28002 Madrid, Spain \\ (Requests for offprints should be addressed to J A Chowen at Instituto Cajal, CSIC, Avendida Dr Arce 37, 28002 Madrid, Spain; Email: chowen@cajal.csic.es)
}

\begin{abstract}
The adult female pituitary has significantly more lactotrophs than that of the male, while the later has a higher percent of somatotrophs. It is clear that $\mathrm{GH}$ and prolactin (PRL) gene expression and somatotroph and lactotroph proliferation are modulated by the postpubertal hormone environment; however, the role of the neonatal steroid environment in this process is not known. We have used in situ hybridization to determine the number of GH and PRL mRNA-containing cells, as well as the level of expression of these two hormones, in response to neonatal and adult testosterone treatment. Female rats exposed to testosterone during the neonatal period, adulthood or both periods, as well as normal females and males were used.

Exposure to testosterone during the neonatal period significantly increased the percentage of somatotrophs (ANOVA: $P<0 \cdot 005)$ and decreased that of lactotrophs in the adult female rat (ANOVA: $P<0 \cdot 001$ ). Adult testosterone treatment had no significant effect on the percentage of somatotrophs. The percentage of lactotrophs was significantly increased by adult testosterone only in those rats
\end{abstract}

also exposed to neonatal testosterone. PRL mRNA concentrations, as reflected by silver grains/cell, were reduced by neonatal testosterone and increased by adult testosterone treatment (ANOVA: P<0.0001). Overall PRL mRNA levels, measured by densitometry, were also reduced by neonatal testosterone exposure, but adult testosterone had no effect (ANOVA: $P<0 \cdot 001$ ). GH mRNA levels per cell, as reflected by silver grains/cell, were increased by adult testosterone, while neonatal testosterone treatment had no effect. Overall GH mRNA levels per unit area, determined by densitometry measurements, were increased by both neonatal and adult testosterone treatment, with the combination of these two treatments resulting in adult females having levels indistinguishable from intact males (ANOVA: $P<0 \cdot 003$ ).

These results suggest that, in combination with postpubertal sex steroids, the neonatal gonadal steroid environment plays an important role in determining anterior pituitary hormone synthesis and cellular composition.

Journal of Endocrinology (2000) 164, 265-276

\section{Introduction}

After the onset of puberty the hormonal output of the anterior pituitary differs substantially between males and females. While females produce and secrete larger quantities of prolactin (PRL), the male pituitary synthesizes significantly more growth hormone (GH) (Birge et al. 1967, Döhler \& Wuttke 1974, Jansson et al. 1985, Tong et al. 1989, Gabriel et al. 1992, González-Parra et al. 1996a). Postpubertal sex steroids are important in generating this phenomenon, but the neonatal gonadal steroid environment is also implicated (Jansson et al. 1985, Jansson \& Frohman 1987a). However, the role of neonatal steroids is less well understood. Development of the neuroendocrine hypothalamus, including those neurons involved in $\mathrm{GH}$ or PRL control, is affected by the neonatal steroid environment (Matsumoto \& Arai 1976, Matsumoto 1991,
Chowen et al. 1992, 1993, Murray \& Gilles 1993, Reznikov \& Nosenko 1995) and various hypothalamic neuropeptides are also implicated in somatotroph and lactotroph development (Chatelain et al. 1979, Billestrup et al. 1986, Hoeffler \& Frawley 1987, Cella et al. 1994, Van Bael et al. 1998, Dean \& Porter 1999). Hence, anterior pituitary development and control could be influenced indirectly by the neonatal steroid environment via modulation of its hypothalamic input, or neonatal steroids could act directly at the level of the pituitary.

In the postpubertal animal, the anterior pituitary of the female has more lactotrophs, while that of the male has a higher percentage of somatotrophs (Takahashi \& Kawashima 1982, Ho et al. 1986, 1988, Hoeffler \& Frawley 1986, González-Parra et al. 1998). These two cell types are derived from a common precursor and require the presence of the transcription factor Pit-1 for their 
development and hormone expression (Li et al. 1991). This transcription factor is differentially expressed in lactotrophs and somatotrophs both in vivo and in vitro (González-Parra et al. 1996a, Chowen et al. 1998) and its regulation by sex steroids and other factors is cell-type specific and highly correlated to changes in PRL and GH gene expression (González-Parra et al. 1996a, Chowen et al. 1998). Modulation of the adult gonadal steroid environment can shift the percentage of GH- or PRL-containing cells, or increase the number of mammosomatotrophs, so that the female anterior pituitary more closely resembles that of the male, or vice versa (Boockfor et al. 1985, Ho et al. 1988, Goth et al. 1996, González-Parra et al. 1998). However, only a relatively small percentage of these cells appear to have the ability to change their hormone production, suggesting that the phenotype of some anterior pituitary cells may be determined during an earlier stage of development and be unchangeable. Indeed, we have previously shown that a larger change in the percentage of both lactotrophs and somatotrophs occurs in the male rat when the neonatal steroid environment is modulated (González-Parra et al. 1998).

The in vivo synthesis and secretion per individual somatotroph or lactotroph also differs between adult female and male rats, with males producing higher levels of GH and females of PRL (Ho et al. 1986, 1988, Hoeffler \& Frawley 1986, González-Parra et al. 1996a). Whether this is due solely to differences in the postpubertal steroid environment is controversial; however, when exposed in vitro to the same sex steroid environment, lactotrophs and somatotrophs of male and female animals have similar levels of PRL and GH mRNA (González-Parra et al. 1998). This suggests that the adult sex steroid environment may be more involved in modulating the level of hormone production, with the neonatal steroid environment playing a more important role in determining the cellular composition of the anterior pituitary.

The aims of this study were as follows. (1) To evaluate the effects of the neonatal steroid environment on $\mathrm{GH}$ and PRL mRNA expression in the adult female pituitary. (2) To determine if the neonatal sex steroid environment modulates the number of lactotrophs and somatotrophs in the adult female anterior pituitary. (3) To examine whether exposure to testosterone during neonatal life influences the ability of the pituitary to modulate these cell populations in response to adult testosterone treatment. (4) To correlate the changes in the number of lactotrophs and somatotrophs with changes in GH and PRL mRNA concentrations.

\section{Materials and Methods}

\section{Animals and housing}

Wistar rats from our in-house breeding colony were housed with a ratio of $12 \mathrm{~h}$ light:12 h darkness, with lights on at $0600 \mathrm{~h}$. They were given free access to rat chow and tap water.

\section{Experimental design}

To assess the effects of sex steroids on GH and PRL mRNA levels and the number of lactotrophs and somatotrophs, female rats were treated with testosterone during the neonatal period (day of birth), adulthood (60 days) or both periods. Neonatal steroid treatment consisted of an s.c. injection of $250 \mu \mathrm{g}$ testosterone, a dose shown to masculinize GH secretory patterns (Jansson \& Frohman 1987a), dissolved in $100 \mu \mathrm{l}$ sesame oil. The neonatal control group received an injection of $100 \mu \mathrm{l}$ sesame oil. The neonatal animals that received sesame oil are referred to as FNO (female neonatal oil) and those receiving sesame oil containing testosterone as FNT (female neonatal testosterone). The intact male group (IM) also received an injection of sesame oil.

At 60 days of age, the animals received the second steroid treatment. Each of the neonatal treatment groups was randomly divided into two groups, one that received an empty Silastic capsule and the other a Silastic capsule containing crystalline testosterone. These capsules were designed to deliver adult male levels of circulating testosterone and their preparation has been described previously (Steiner et al. 1982). These treatments resulted in the following experimental groups: FNOAO (female, neonatal oil, adult oil), FNTAO (female, neonatal testosterone, adult oil), FNOAT (female, neonatal oil, adult testosterone), FNTAT (female, neonatal testosterone, adult testosterone) and IM (intact male). To minimize fluctuation in the results for cyclic females, in the group that had estrous cycles (FNOAO) only those females exhibiting at least two consecutive 4-day cycles were used and were killed on the morning of estrus. This day was chosen since females treated with testosterone are in a state similar to constant estrus. All animals were killed between 75 and 77 days of age between 0900 and $1100 \mathrm{~h}$.

To determine overall mRNA levels for each peptide, in situ hybridization using a radioactive probe was performed. To determine the number of either lactotrophs or somatotrophs per unit area, riboprobes labeled with digoxigenin were employed.

\section{Tissue preparation for in situ hybridization}

On the day on which they were killed, animals were asphyxiated with carbon dioxide and immediately decapitated. The pituitaries were removed, rapidly frozen on dry ice, and stored intact at $-80^{\circ} \mathrm{C}$ until processed for in situ hybridization histochemistry. Trunk blood was collected at the time of decapitation and separated by centrifugation. The serum was stored at $-20{ }^{\circ} \mathrm{C}$ until assayed for testosterone. 
Before cutting, pituitaries were allowed to equilibrate in the cryostat $\left(-17^{\circ} \mathrm{C}\right)$ and embedded in OCT (Tissue-Tek, Elkhart, IN, USA). Sections $(12 \mu \mathrm{m})$ were thaw-mounted onto poly-L-lysine-coated slides. Tissue slices were stored at $-80{ }^{\circ} \mathrm{C}$ in airtight boxes until hybridization histochemistry was performed.

\section{Riboprobe preparation}

The original plasmid, pBR322-GH1, contains a $790 \mathrm{bp}$ insert of a rat GH cDNA clone (Harpold et al. 1978, Dobner et al. 1981). A 451 bp Ava I/Pvu II fragment of this clone was further subcloned into a pGem3Z vector. This plasmid was kindly provided by P M Martha Jr, Baustate Medical Center, Springfield, MA, USA. The plasmids, SP65-1 and SP65-2, each containing a 780 bp fragment of the PRL cDNA, but in opposite directions, were used to transcribe antisense and sense PRL probes respectively. These plasmids were provided by $\mathrm{RA}$ Maurer (Gubbins et al. 1979, 1980).

In vitro transcription with $\mathrm{S}^{35}$-UTP for radioactive probes was carried out as previously described (Chowen et al. 1991) and resulted in a specific activity of approximately $1.3 \times 10^{8}$ d.p.m. $/ \mu$ g for both $\mathrm{GH}$ and PRL. Transcription of digoxigenin probes was carried out according to the manufacturer's instructions (Boehringer Mannheim, Mannheim, Germany). All probes were hydrolyzed to approximately 150 bases in $100 \mathrm{mM}$ bicarbonate $(\mathrm{pH} 10 \cdot 2)$ at $60{ }^{\circ} \mathrm{C}$.

\section{In situ hybridization}

After fixation in $4 \%$ paraformaldehyde, tissue sections were pretreated with $0 \cdot 25 \%$ acetic anhydride in $0 \cdot 1 \mathrm{M}$ triethanolamine $(\mathrm{pH} 8.0)$ for $10 \mathrm{~min}$. The slides were rinsed in $2 \times \mathrm{SSC}(300 \mathrm{mM} \mathrm{NaCl}$ and $30 \mathrm{mM} \mathrm{Na}$ citrate) and blotted. The probes were applied in $60 \mu \mathrm{l}$ hybridization buffer at saturating concentrations. The slides were then covered with a strip of parafilm, sealed with rubber cement, and incubated overnight in moist chambers at $45^{\circ} \mathrm{C}$. The following day, the parafilm coverslips were peeled off and the slides rinsed in $4 \times$ SSC. After RNAase treatment and a series of washes in SSC of increasing stringency, the slides were dehydrated in alcohol and air-dried.

Slides were dipped in Kodak NTB-2 emulsion (Eastman Kodak, Rochester, NY, USA) that had been diluted 1:1 with $600 \mathrm{mM}$ ammonium acetate and heated to $45{ }^{\circ} \mathrm{C}$ in a water bath. They were allowed to air-dry for $15 \mathrm{~min}$, then further dried in a moist chamber at room temperature for $1 \mathrm{~h}$. Slides were placed in light-tight boxes containing desiccant and exposed for 4 days (PRL) or 5 days $(\mathrm{GH})$ at $4{ }^{\circ} \mathrm{C}$. For all assays, slides were developed and counterstained with cresyl violet, and coverslips were then applied. (For more detail see Chowen et al. 1991.)
In situ hybridization assays with digoxigenin probes were performed equal to that for radioactive probes through the final wash in $0 \cdot 1 \times \mathrm{SSC}$; thereafter, instead of dehydrating the slides, they were incubated with $2 \times$ SSC containing $0.5 \%$ Triton X-100 and 2\% normal sheep serum for $1 \mathrm{~h}$ at room temperature. The slides were then washed in buffer 1 (100 mM Tris- $\mathrm{HCl}, \mathrm{pH} 7 \cdot 5,150 \mathrm{mM} \mathrm{NaCl}$ ) twice (10 min each) and incubated overnight at $4{ }^{\circ} \mathrm{C}$ with antidigoxigenin antibody conjugated to alkaline phosphatase (Boehringer Mannheim; 1:1000 in buffer 1 containing 1\% normal sheep serum and $0 \cdot 4 \%$ Triton X-100). The slides were washed once in buffer $1(10 \mathrm{~min})$ and then buffer 2 (100 mM Tris-HCl, pH 9.5, $100 \mathrm{mM} \mathrm{NaCl}, 50 \mathrm{mM}$ $\mathrm{MgCl}_{2}$ ) twice for $10 \mathrm{~min}$ each. They were then incubated in $338 \mu \mathrm{g} / \mathrm{ml}$ nitroblue tetrazolium-chloride, $175 \mu \mathrm{g} / \mathrm{ml}$ 5-bromo-4-chloro-3-indolyl-phosphate (Boehringer Mannheim) and $240 \mu \mathrm{g} / \mathrm{ml}$ levamisole (Sigma Chemical Co., St Louis, MO, USA) in buffer 2 in a light-tight box overnight at room temperature. The following day the reaction was stopped in $10 \mathrm{mM}$ Tris- $\mathrm{HCl}, \mathrm{pH} 8.0$ and $1 \mathrm{mM}$ EDTA. The slides were rapidly dehydrated and coverslipped.

\section{Control experiments}

Control experiments, including employment of sense riboprobes and saturation curves, were performed for the riboprobes to verify their specificity and to determine the optimum concentration of probe for the quantitative assays. These results have been published previously (González-Parra et al. 1996a,b). As expected, specific binding of both riboprobes was seen over the anterior pituitary and not the posterior pituitary.

\section{Image analysis system}

Eight tissue sections throughout the entire anterior pituitary from each animal were included in the analysis of mRNA concentration. Slides selected for analysis were assigned a random three-letter code and analyzed in alphabetical, hence random, order by an operator unaware of the experimental group to which the animal belonged. The automated image-processing system consists of a Pixel Grabber video acquisition board (Perceptics Corp., Knoxville, TN, USA) attached to a Macintosh IIci computer. The software, Image, supplied by the National Institutes of Health, was used for densitometric analysis of tissue sections and Grains, written by D K Clifton at the University of Washington, Seattle, WA, USA, was used to determine grains/cell. Video images were obtained by a Sony camera (Sony Corporation, Japan) attached to a Zeiss Axioplan Photomicroscope.

To determine the relative level of specific mRNA per cell, the number of silver grains/individual cell was analyzed in approximately 100 cells per animal. A background reading was taken with each individual cell analysis and automatically subtracted. One difficulty with 
this analysis was the close proximity of the anterior pituitary cells, which limits the availability of some cells for analysis. Only cells that could be individually isolated were analyzed with this system, which could bias the data. This caveat should be taken into consideration.

For densitometric analysis, darkfield illumination with a $\times 20$ magnification objective was used. In each tissue section, approximately ten different fields were selected and analyzed (approximately 80 readings/animal). Each field included only the anterior pituitary and had a clear signal free of artifacts. Background readings were taken in each section by measuring the non-specific signal over the posterior pituitary. The specific signal in each section was then calculated by subtracting the mean density obtained in the posterior pituitary from that obtained in the anterior pituitary. The non-specific signal over the posterior pituitary did not differ significantly between the experimental groups or within a group and did not exceed $10 \%$ of the specific signal.

The relationship between increasing concentrations of radioactivity and densitometry readings in this assay system has been reported previously, as well as the relationship between the signals received with in situ hybridization and protection assays (Chowen et al. 1991). Furthermore, it was verified that with increasing amounts of radioactive probe applied to the sections an increase in signal was detected with all probes until the available binding sites were saturated. All assays were run at saturating concentrations. Therefore, the densitometry readings reported reflect relative levels of specific mRNA signal and are reported as densitometry units.

The number of GH mRNA- or PRL mRNAcontaining cells was determined by analyzing six tissue sections/animal dispersed throughout the entire anterior pituitary. Using a $\times 100$ objective, the operator counted the number of positive cells in 12 different fields in each section (12 fields/section, 6 tissue sections or 72 fields per pituitary). A cell was determined to be positive if the intensity of its labeling was at least 5\% higher than the mean background reading taken over cells of the posterior pituitary. The mean number of unlabeled cells per area was also determined so that the percentage of labeled cells could be determined.

\section{Serum testosterone assay}

Trunk blood was collected when the animals were killed and allowed to clot. It was then centrifuged and the serum separated and stored at $-20{ }^{\circ} \mathrm{C}$ until assayed. Using an antibody and standard supplied by the WHO Matched Reagent programme, testosterone levels were measured by RIA, as previously described (Matsumoto et al. 1983). The sensitivity of this assay was $0.17 \mathrm{nmol} / 1$ in a $100 \mu \mathrm{l}$ sample. The intra- and inter-assay coefficients of variations were $4 \cdot 0 \%$ and $10 \%$ respectively.

\section{Statistical analysis}

For both GH and PRL, approximately 100 cells/animal were analyzed to obtain the mean grains/cell for each animal. The mean number of densitometry units for each animal was determined from the analysis of approximately 80 fields of view per animal. The mean number of cells per unit area was calculated from the analysis of approximately 72 fields per animal. The mean for each animal was then used to determine the means \pm s.E.M. for each experimental group, with the $n$ in all statistical analyses referring to the number of animals in the group ( $n=5$ per group). To determine whether there was an interaction between neonatal steroid treatment and adult steroid treatment on either cell number or overall mRNA levels, a two-way analysis of variance (ANOVA) was performed. A one-way ANOVA followed by a Scheffé $F$ test was performed to determine whether differences between the various groups existed. The significance level was chosen as $P<0 \cdot 05$.

\section{Results}

\section{Number of GH mRNA-containing cells}

Figure 1 is a representative section through the anterior pituitary of a normal female (Fig. 1A) and a female treated with testosterone both as a neonate and adult (Fig. 1B). The darkly labeled cells represent those that are GH mRNA positive. The number of labeled cells and nonlabeled cells per field was assessed. The total number of cells per view was not significantly different in any of the experimental groups.

The mean percentage of GH mRNA-positive cells per unit area was significantly lower in female rats as compared with males (Fig. 1C; ANOVA: $P<0 \cdot 005$ ). Those animals exposed to testosterone during the neonatal period had a significantly higher percentage of GH mRNA-containing cells compared with those not exposed to testosterone during this time-period (FNTAO vs FNOAO). Adult testosterone treatment had no significant effect.

\section{Number of PRL mRNA-containing cells}

Figure $2 \mathrm{~A}$ is a section through the anterior pituitary of a normal female and Fig. $2 \mathrm{~B}$ that of a female treated with testosterone both as a neonate and as an adult. The darkly labeled cells represent those that are PRL mRNA positive. The number of labeled cells and nonlabeled cells per field was assessed. The total number of cells per view was not significantly different in any of the experimental groups.

Normal female rats had significantly more PRL mRNA-containing cells per unit area when compared with males (Fig. 2C; ANOVA: $P<0 \cdot 001$ ). Exposure to testosterone during the neonatal period significantly decreased the number of PRL mRNA-containing cells (FNTAO vs FNOAO and FNTAT vs FNOAT). Adult 

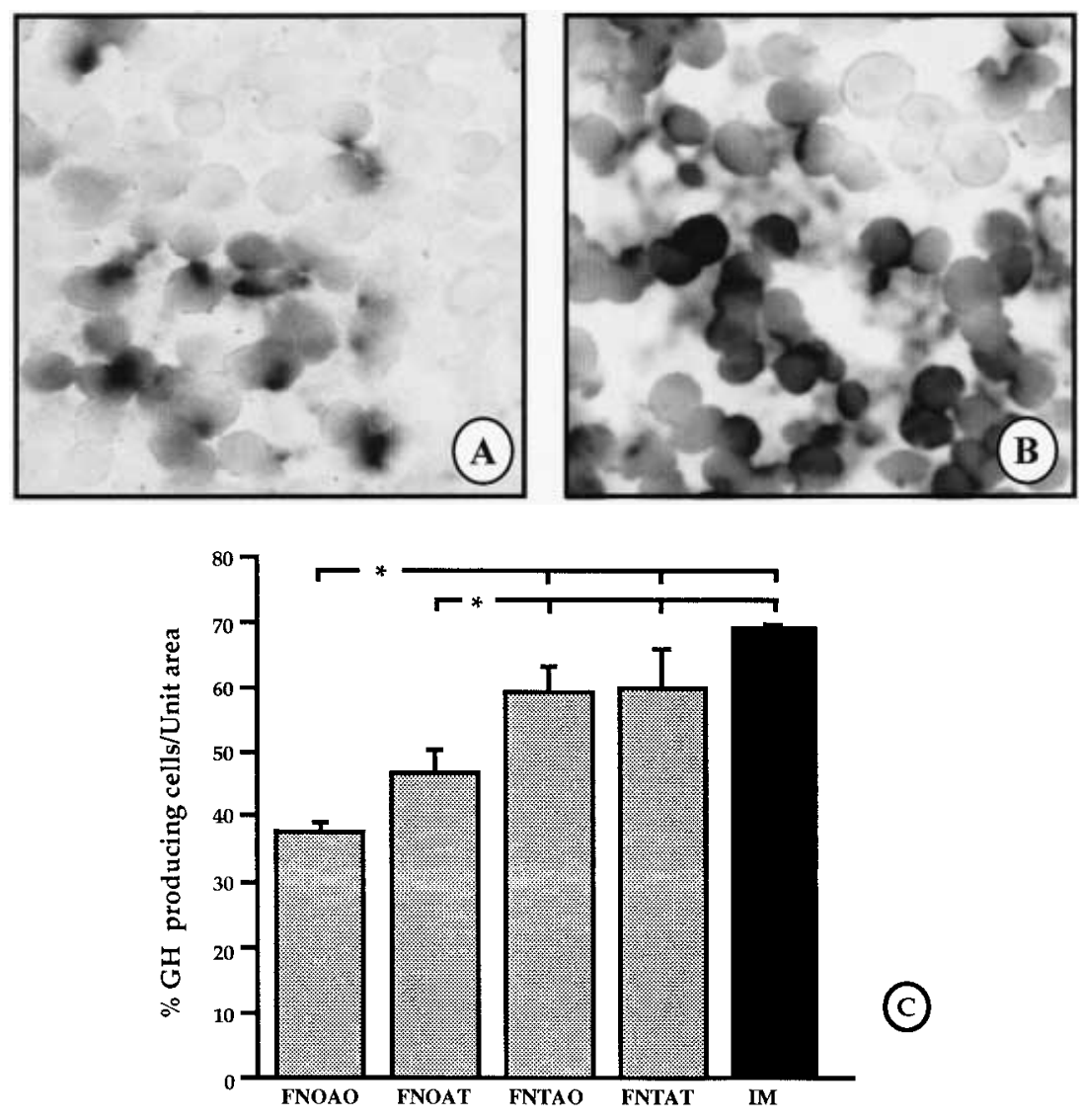

Figure 1 Brightfield photomicrographs of sections through the anterior pituitaries of a normal adult female rat $(\mathrm{A})$ and a female treated with testosterone on the day of birth and during adulthood (B) on which in situ hybridization to detect GH mRNA was performed. The darkly stained cell bodies represent GH mRNA-containing cells. (C) Mean percentage $( \pm$ S.E.M.) of $\mathrm{GH}$ mRNA-containing cells/unit area in the anterior pituitary. $\mathrm{FNOAO}=$ normal female, FNOAT $=$ female receiving testosterone during adulthood, $\mathrm{FNTAO}=$ female receiving testosterone as a neonate, FNTAT $=$ female receiving testosterone both as a neonate and an adult, IM=intact male. ${ }^{*} P<0 \cdot 005:$ ANOVA; $n=5$ in each group.

steroid treatment increased the percentage of PRL mRNA-containing cells, but this was only significant in those animals that were also exposed to testosterone during the neonatal period (FNTAO vs FNTAT).

\section{GH $m R N A$ levels}

GH mRNA levels per individual cell, as represented by grains/cell, were significantly higher in intact males compared with normal estrous females (Fig. 3A). Neonatal testosterone treatment did not significantly affect $\mathrm{GH}$ mRNA levels per individual cell. Adult testosterone treatment increased GH mRNA levels and this response was not affected by neonatal testosterone treatment.

The overall GH mRNA density level was significantly lower in normal females compared with males (Fig. 3B). Both neonatal and adult testosterone treatments significantly increased GH mRNA density levels (ANOVA:
$P<0 \cdot 003)$. Furthermore, exposure to testosterone during the neonatal period significantly increased the response to adult testosterone treatment (two-way ANOVA: $P<0 \cdot 01)$. The effect of neonatal and adult testosterone was additive, resulting in females exposed to testosterone during both periods having GH mRNA levels similar to those found in intact males.

In Fig. 4 the difference in GH mRNA signal density between a normal female (Fig. 4A) and a female treated with testosterone during both the neonatal and adult period (Fig. 4B) can be appreciated.

\section{PRL mRNA levels}

Mean PRL mRNA concentration per cell was significantly higher in normal females compared with males (Fig. 5A; ANOVA: P<0·0001). Neonatal testosterone treatment significantly reduced PRL mRNA 

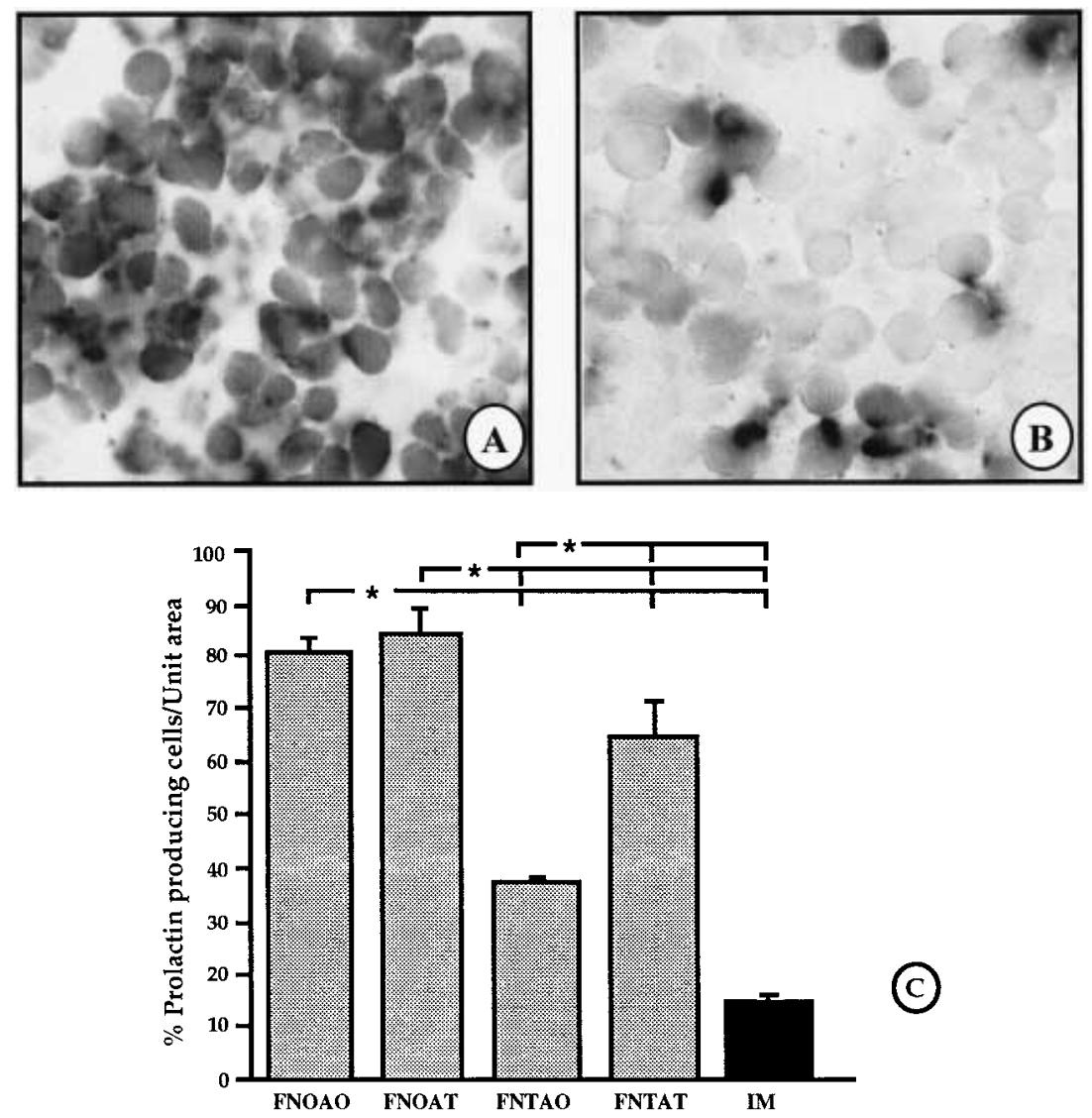

Figure 2 Brightfield photomicrographs of sections through the anterior pituitaries of a normal female rat $(A)$ and a female treated with testosterone both as a neonate and an adult (B) on which in situ hybridization to detect PRL mRNA was performed. The darkly stained cell bodies represent PRL mRNA-containing cells. (C) Mean percentage ( \pm S.E.M.) of PRL mRNA-containing cells/unit area in the anterior pituitary. FNOAO=normal female, $\mathrm{FNOAT}=$ female receiving testosterone during adulthood, $\mathrm{FNTAO}=$ female receiving testosterone as a neonate, FNTAT $=$ female receiving testosterone as a neonate and adult, $\mathrm{IM}=$ intact male. ${ }^{*} P<0 \cdot 001:$ ANOVA; $n=5$ in each group.

concentration/cell in the adult female rat. Adult testosterone had no effect on female rats not exposed to neonatal testosterone; however, it significantly increased PRL mRNA levels in those females treated with neonatal testosterone. Hence, the neonatal sex steroid environment modulated the response of lactotrophs in the adult animal to testosterone (two-way ANOVA: $P<0 \cdot 0001$ ).

Overall PRL mRNA density levels were significantly higher in females compared with males (Fig. 5B, ANOVA: $P<0 \cdot 001)$. Treatment of female animals with testosterone during the neonatal period resulted in a significant reduction in overall PRL mRNA levels, while adult testosterone treatment had no significant effect.

In Fig. 6 the difference in PRL mRNA signal density between a normal female (Fig. 6A) and a male (Fig. 6B) can be appreciated.

\section{Testosterone levels}

The testosterone levels are shown in Table 1. The serum testosterone levels of the intact male and female rats were in the normal physiological range. Neonatal treatment with testosterone did not affect adult steroid levels. Animals treated with Silastic capsules containing testosterone had levels within the physiological range for intact adult males.

\section{Discussion}

The early postnatal hormone environment can have dramatic effects on the anterior pituitary since this gland is relatively immature at birth and continues to develop throughout neonatal life (Smets et al. 1989, Simmons 


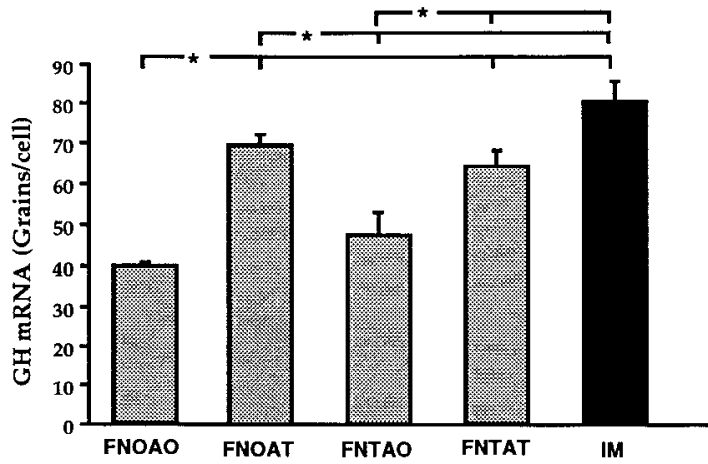

(A)

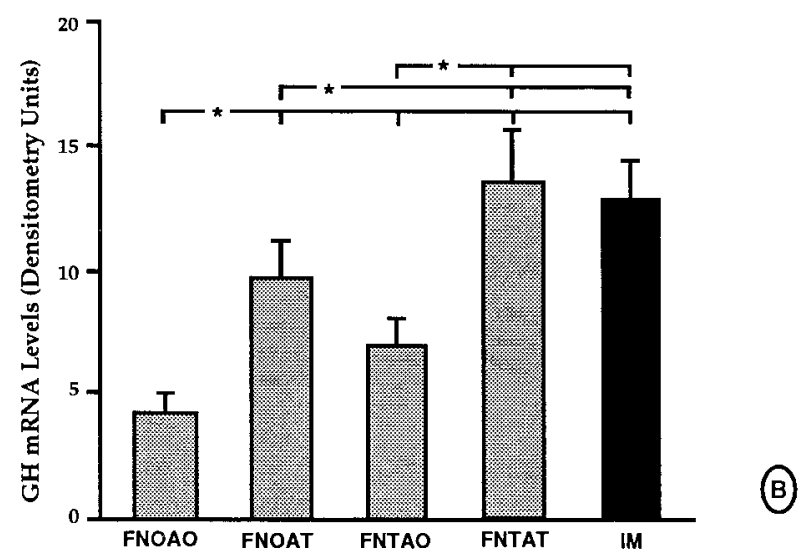

Figure 3 Comparison of relative mean concentrations of $\mathrm{GH}$ mRNA in the anterior pituitary of normal females (FNOAO), females receiving testosterone as adults (FNOAT), females receiving testosterone during neonatal life (FNTAO), females receiving testosterone both as neonates and adults (FNTAT) and intact males (IM). $n=5$ in each group. (A) GH mRNA concentrations/cell, as determined by grains/cell, ${ }^{*} P<0 \cdot 0001$ : ANOVA. (B) GH mRNA concentrations per unit area as determined by densitometry, ${ }^{*} P<0 \cdot 003$ : ANOVA.

1990). During adulthood, this gland remains under a dynamic state of cellular turnover with apparently fully differentiated cells undergoing mitotic division, with the majority of these proliferating cells expressing either $\mathrm{GH}$ or PRL (Dada et al. 1984, Carbajo-Pérez \& Watanabe 1990, Oishi et al. 1993). Although there is active cellular turnover, the phenotypic make-up of the anterior pituitary is maintained unless the surrounding milieu is changed. Indeed, if the gonadal steroid environment is modulated the percentage of lactotrophs and somatotrophs can be shifted. However, in both adult males (González-Parra et al. 1998) and females, as shown here, the percentage of cells capable of changing their phenotype may be limited.

The cellular composition and size of the pituitary begin to differ between the sexes after the onset of puberty when the proliferation of anterior pituitary cells in the female starts to exceed that in males (Takahashi \& Kawashima
1982, Hoeffler \& Frawley 1987, Carbajo-Pérez \& Watanabe 1990, Oishi et al. 1993). Postpubertal females have larger anterior pituitaries (Hoeffler \& Frawley 1987, Carbajo-Pérez \& Watanabe 1990) with a higher percentage of lactotrophs, while pituitaries of males contain a higher percentage of somatotrophs (Takahashi \& Kawashima 1982, Ho et al. 1986, 1988, Hoeffler \& Frawley 1986). Our results are in agreement with these findings and the proportion of each cell type reported here is similar to that found previously by using protein content or secretion for identification of cell type (Takahashi \& Kawashima 1982, Ho et al. 1986, 1988, Hoeffler \& Frawley 1986, Goth et al. 1996). Hence, in situ hybridization is at least as sensitive as these other techniques in detecting lactotrophs and somatotrophs and the differences reported here are not due to our inability to detect cells producing low levels of the hormone in question.

Testosterone treatment during only the adult period increased the number of lactotrophs in female rats by less than $5 \%$ and the overall percentage of somatotrophs by approximately $10 \%$. These changes are similar to those reported previously in males (Ho et al. 1988, GonzálezParra et al. 1998) and suggest that the percentage of cells in the normal adult female pituitary that can be recruited to shift between GH or PRL expression is also limited. In contrast, adult testosterone treatment increased lactotrophs by approximately $30 \%$ in females exposed to testosterone neonatally. Hence, the neonatal environment may be important for determining the later responsiveness of these cells to changes in the steroid environment.

Modulation of the neonatal steroid environment has a dramatic effect on the cellular composition of the anterior pituitary. Exposure to testosterone during only the neonatal period reduced the number of lactotrophs by over $40 \%$ and increased the number of somatotrophs by approximately $20 \%$. This resulted in the pituitary composition being more similar to that of an adult male and further demonstrates that the neonatal environment is involved in determining the cellular composition of the anterior pituitary gland.

Hypothalamic factors are undoubtedly important for development of the anterior pituitary (Chatelain et al. 1979, Hoeffler \& Frawley 1987, Smets et al. 1989, Cella et al. 1994, Van Bael et al. 1998, Dean \& Porter 1999) and whether the observed effects of sex steroids are mediated directly on the pituitary or via the hypothalamus remains to be determined. Expression of the transcription factor Pit-1 correlates temporally to when the developing pituitary and hypothalamus become physically connected and production of Pit-1 protein is followed by GH and PRL expression (Smets et al. 1989, Dollé et al. 1990). Pit-1 is involved in the expression of the GH-releasing hormone $(\mathrm{GHRH})$ receptor in the pituitary (Lin et al. 1992) and GHRH stimulates somatotroph proliferation in vitro (Billestrup et al. 1986). Transient lack of GHRH during development causes a decrease in $\mathrm{GH}$ production in 

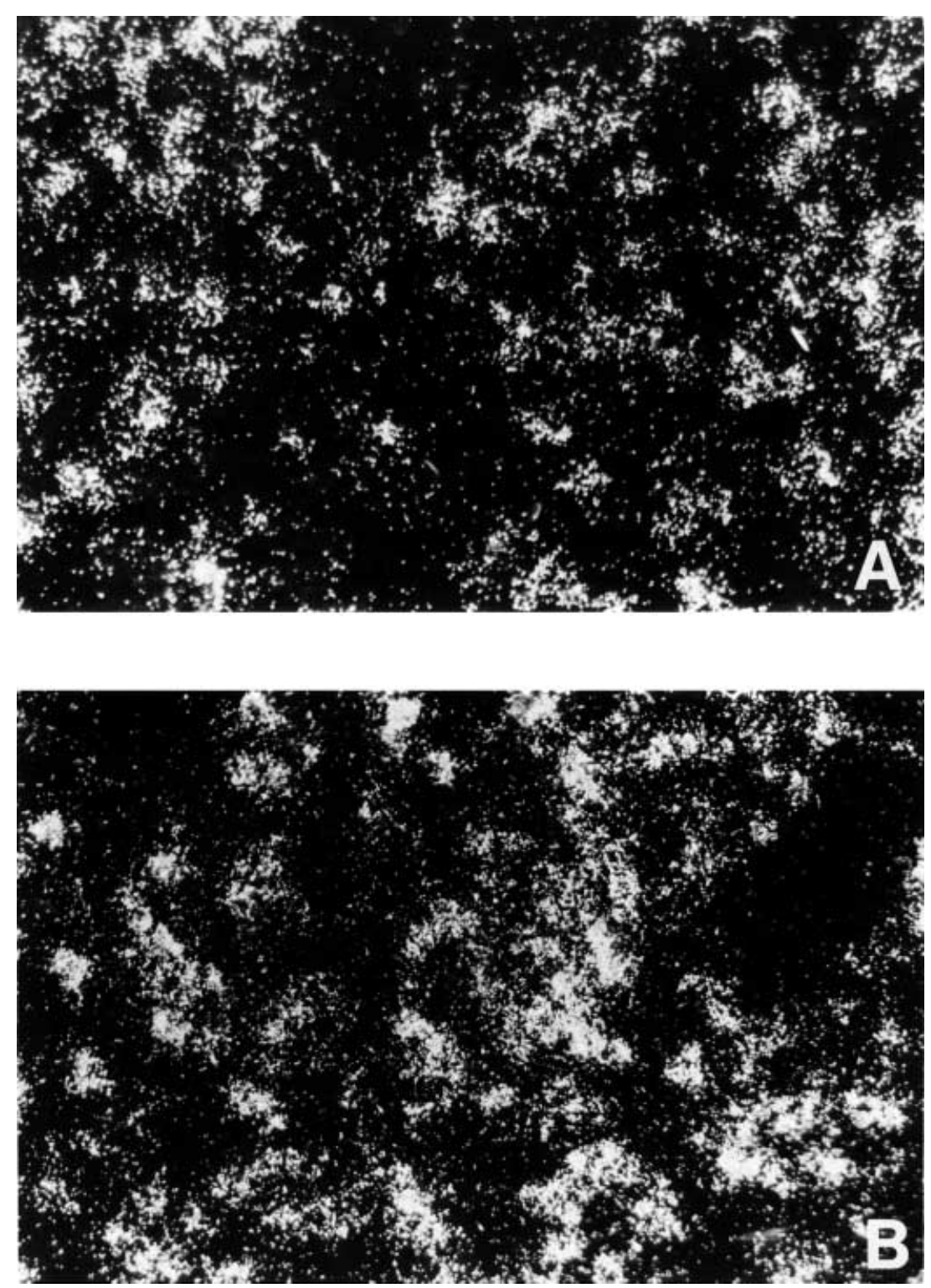

Figure 4 Darkfield photomicrograph of a section through the pituitary of an estrous female (A) and a female treated with testosterone on the day of birth and during adulthood (B) on which in situ hybridization was performed to detect GH mRNA. The white grain clusters represent $\mathrm{GH}$ mRNA-positive cells.

the adult, as well as a reduced response to GHRH (Cella et al. 1994). Furthermore, when hypothalamic input is lacking, more lactotrophs develop (Shiino et al. 1977). These results could suggest that GHRH stimulates somatotroph proliferation and may be important for stopping cell development at this level, impeding the progression to lactotrophs. Other factors, such as estrogens, may function to shift the development towards lactotrophs. Indeed, activation of the estrogen receptor in conjunction with Pit-1 is necessary for lactotroph development
(Simmons et al. 1990) and estrogen decreases GHRH receptor mRNA levels in the pituitary (Lam et al. 1996), which could decrease GH expression. In contrast, expression of GHRH is increased by both neonatal and postpubertal testosterone (Zeitler et al. 1992, Chowen et al. 1993) and is sexually dimorphic during the neonatal period (Argente et al. 1991) when the anterior pituitary is in a highly active phase of proliferation (Carbajo-Pérez \& Watanabe 1990). Hence higher GHRH levels in male animals (Jansson et al. 1985, Argente et al. 1991) 

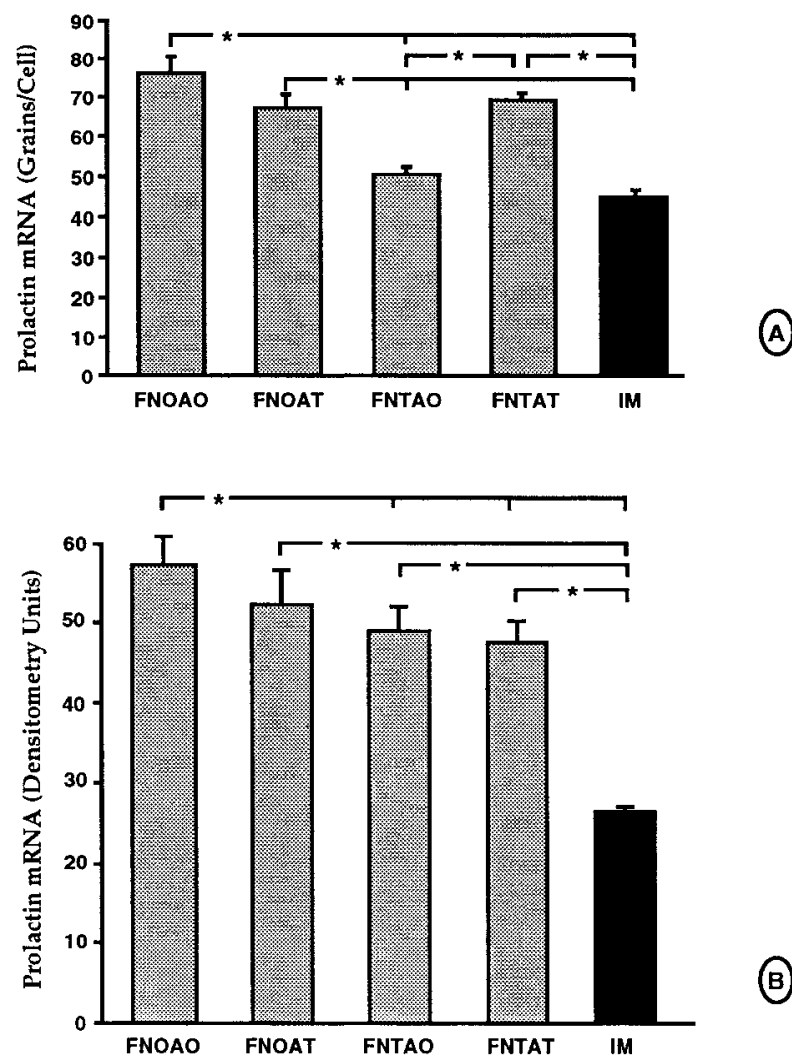

(B)

Figure 5 Comparison of relative mean levels of PRL mRNA in the anterior pituitary of normal female rats (FNOAO), females receiving testosterone as adults (FNOAT), females receiving testosterone during neonatal life (FNTAO), females receiving testosterone both as neonates and adults (FNTAT) and intact males (IM). $n=5$ in each group. (A) PRL mRNA concentrations/cell, as determined by grains/cell, ${ }^{*} P<0 \cdot 0001$ : ANOVA. (B) PRL mRNA concentrations per unit area as determined by densitometry, ${ }^{*} P<0 \cdot 001$; ANOVA.

may induce the development of a higher percentage of somatotrophs and fewer lactotrophs.

Both androgen and estrogen receptors are found in the developing and adult pituitary gland (Keefer \& Holdeegger 1985, Babichev et al. 1990, Burgess \& Handa 1993, Scully et al. 1997, Wilson et al. 1998) and both classes of steroids may be involved in determining the cellular composition of the anterior pituitary. Disruption of the estrogen receptor- $\alpha$ results in a decrease in lactotroph number and PRL production, but an increase in GH production (Scully et al. 1997), suggesting that the effects on lactotrophs may be via the estrogen receptor with little or no estrogen effect on somatotroph number. Neonatal castration of male rats reduces androgen receptors in the adult pituitary (Babichev et al. 1990), which may be due to a decrease in the number of cells expressing this receptor or the number of receptors per cell. In vitro, lactotrophs and somatotrophs from male and female rats have similar changes in mean GH, PRL and Pit-1 mRNA levels per cell in response to sex steroids (Chowen et al. 1998), suggesting that individual cells from the two sexes have a similar responsiveness to gonadal steroids and, hence, may express similar levels of the receptors for these steroids.

The number of GH-expressing cells/area is not significantly modified by adult testosterone treatment, but GH mRNA levels/cell are increased and this is also reflected in an increase in GH mRNA density levels. This increase in $\mathrm{GH}$ expression/cell might augment our ability to detect low expressing cells and explain the slight increase in the percentage of $\mathrm{GH}$ mRNA-containing cells after adult testosterone treatment and not reflect a true increase in somatotrophs/area. Neonatal testosterone increases the percentage of GH mRNA-containing cells/area and GH mRNA levels/area, but has no significant effect on GH mRNA levels/cell. Hence, both neonatal and adult testosterone treatments increase GH mRNA density, but through different mechanisms. In the adult animal, the in vivo effects of testosterone on $\mathrm{GH}$ mRNA levels per individual cell are most likely via modulation of GHRH and somatostatin (Chowen-Breed et al. 1989, Argente et al. 1990, Zeitler et al. 1992), since GH gene expression is not modulated in vitro by this steroid (González-Parra et al. 1996b, Chowen et al. 1998).

When female rats were exposed to testosterone during the neonatal period, PRL mRNA levels/unit area, grains/ cell and the percentage of lactotrophs decreased significantly. Therefore, neonatal exposure to testosterone decreases both the number of PRL-producing cells and their level of synthesis. Adult testosterone treatment stimulates the percentage of lactotrophs and PRL mRNA levels/cell, but only in animals exposed to neonatal testosterone. In normal females, adult testosterone treatment had no significant effect on either the number of lactotrophs or PRL mRNA levels. This result was unexpected since testosterone, via aromatization to estradiol and acting at the level of the pituitary, stimulates PRL mRNA levels (Shull et al. 1987, Waterman et al. 1988, Chowen et al. 1998, González-Parra et al. 1996b). Estrogen also stimulates the proliferation of lactotrophs (Pérez et al. 1986, Ho et al. 1988, Ellerkmann et al. 1991). It is possible that longer exposure to testosterone, in this case 2 weeks, does not have the same effect on lactotrophs from female animals as does acute exposure.

The effects of neonatal and adult testosterone treatment in female animals were very similar to those observed previously in male rats (González-Parra et al. 1998). One striking difference was observed in overall PRL mRNA levels. Treatment with testosterone during only the adult period significantly increased PRL mRNA levels in males while in the female there was no significant effect. On the other hand, neonatal testosterone significantly reduced PRL mRNA levels in females and slightly increased them in males. One caveat that must be taken into consideration is that these females were not ovariectomized and 

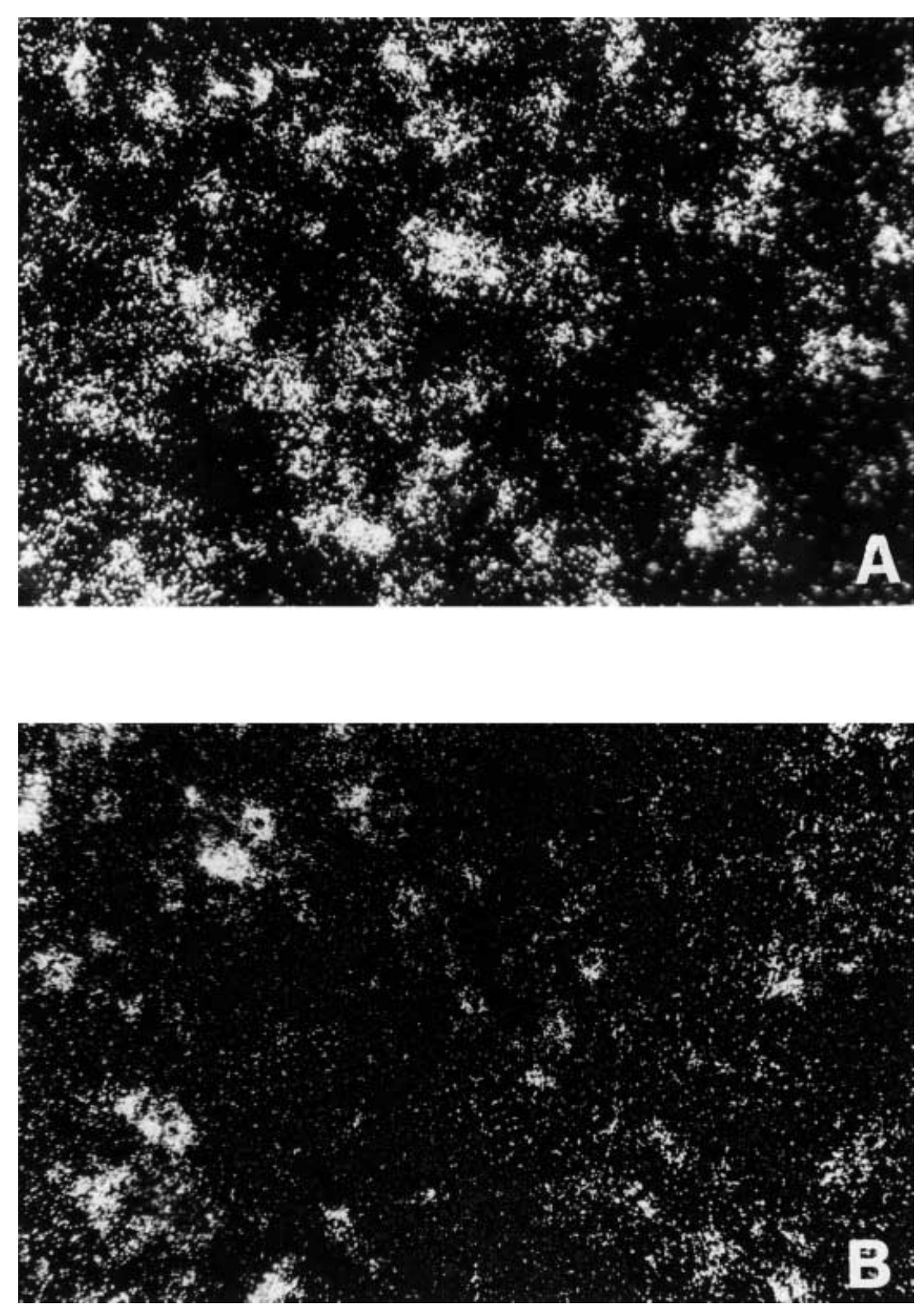

Figure 6 Darkfield photomicrograph of a section through the pituitary of an estrous female rat $(\mathrm{A})$ and a female rat treated with testosterone during the neonatal period (B) on which in situ hybridization to detect PRL mRNA was performed. The white grain clusters represent PRL mRNA-positive cells.

Table 1 Mean levels of serum tesotsterone (nmol/l). Values are means \pm S.E.M.

\begin{tabular}{lllll} 
FNOAO & FNOAT & FNTAO & FNTAT & IM \\
\hline $0 \cdot 8 \pm 0 \cdot 09$ & $\frac{1}{10 \cdot 0 \pm 0 \cdot 6}$ & $\frac{10 \cdot 6 \pm 0 \cdot 6}{10 \cdot 3 \pm 2 \cdot 7}$
\end{tabular}

See Experimental design for explanation of the various gropus secretions by the ovaries may be inhibitory to or modulate some of these processes (Jansson \& Frohman 1987b).

We have shown that both the neonatal and adult steroid environments are important in determining GH and PRL expression levels in the adult female rat and this is partially due to influences on the cellular composition of the anterior pituitary. Although it is well accepted that gonadal 
steroids can modulate the number of somatotrophs and lactotrophs in the anterior pituitary of the adult rat, we suggest that the extent of this phenomenon may be limited and the final percentage of a specific cell type is more dependent on the neonatal steroid environment to which the animal is exposed.

\section{Acknowledgements}

We should like to thank Joaquín Sancho for excellent technical support. This work was sponsored by Comunidad de Madrid grant No. 08.5/0009/1997 (L M G-S), Fundación Endocrinología y Nutrición, and Lilly, S.A., Spain.

\section{References}

Argente J, Chowen-Breed J, Steiner RA \& Clifton DK 1990 Somatostatin messenger RNA in hypothalamic neurons is increased by testosterone through activation of androgen receptors and not by aromatization to estradiol. Neuroendocrinology 52 342-349.

Argente J, Chowen JA, Zeitler P, Clifton DK \& Steiner R 1991 Sexual dimorphism of growth hormone-releasing hormone and somatostatin gene expression in the hypothalamus of the rat during development. Endocrinology 128 2369-2375.

Babichev VN, Shishkina IV \& Peryshkova TA 1990 The effect of neonatal castration of male rats on the level of sex-hormone receptors in the hypothalamus and hypophysis of adult animals. Biomedical Sciences 1 189-192.

Billestrup N, Swanson LW \& Vale W 1986 Growth hormonereleasing factor stimulates proliferation of somatotrophs in vitro. Proceedings of the National Academy of Sciences of the USA $\mathbf{8 3}$ 6854-6857.

Birge CA, Peake GT, Mariz IK \& Daughaday WH 1967 Radioimmunoassayable growth hormone in the rat pituitary gland: effects of age, sex and hormonal state. Endocrinology 81 195-204.

Boockfor R, Hoeffler JP \& Frawley LS 1985 Cultures of GH3 cells are functionally heterogeneous: thyrotropin-releasing hormone, estradiol and cortisol cause reciprocal shifts in the proportions of growth hormone and prolactin secretors. Endocrinology 117 418-420.

Burgess LH \& Handa RJ 1993 Hormonal regulation of androgen receptor mRNA in the brain and anterior pituitary gland of the male rat. Molecular Brain Research 19 31-38.

Carbajo-Pérez E \& Watanabe YG 1990 Cellular proliferation in the anterior pituitary of the rat during the postnatal period. Cell and Tissue Research 261 333-338.

Cella SG, Locatelli V, Broccia ML, Menegola E, Giavini E, De Gennaro Colonna V, Torsello A, Wehrenberg WB \& Muller EE 1994 Long-term changes of somatotrophic function induced by deprivation of growth hormone-releasing hormone during the fetal life of the rat. Journal of Endocrinology 140 111-117.

Chatelain A, Dupouy JP \& Dubois MP 1979 Ontogenesis of cells producing polypeptide hormones (ACTH, MSH, LPH, GH, and prolactin) in the fetal hypophysis of the rat: influence of the hypothalamus. Cell and Tissue Research 196 409-413.

Chowen-Breed JA, Steiner RA \& Clifton DK 1989 Sexual dimorphism and testosterone-dependent regulation of somatostatin gene expression in the periventricular nucleus of the rat brain. Endocrinology 125 357-362.

Chowen JA, Steiner RA \& Clifton DK 1991 Semiquantitative analysis of cellular somatostatin mRNA levels by in situ hybridization histochemistry. In Methods in Neuroscience, vol 5, pp 137-158. Ed PM Conn. San Diego: Academic Press.
Chowen JA, Torres-Alemán I \& García-Segura LM 1992 Trophic effects of estradiol on fetal rat hypothalamic neurons. Neuroendocrinology 56 895-901.

Chowen JA, Argente J, González-Parra S \& García-Segura LM 1993 Differential effects of the neonatal and adult sex steroid environments on the organization and activation of hypothalamic growth hormone-releasing hormone and somatostatin neurons. Endocrinology 133 2792-2802.

Chowen JA, González-Parra S, García-Segura LM \& Argente J 1998 Sexually dimorphic interaction of insulin-like growth factor (IGF-1) and sex steroids in lactotrophs. Journal of Neuroendocrinology $\mathbf{1 0}$ 493-502.

Dada MO, Campbell GT \& Blake CA 1984 Pars distalis cell quantification in normal adult male and female rats. Journal of Endocrinology 101 87-94.

Dean CE \& Porter TE 1999 Regulation of somatotroph differentiation and growth hormone $(\mathrm{GH})$ secretion by corticosterone and $\mathrm{GH}-$ releasing hormone during embryonic development. Endocrinology 140 1104-1110.

Dobner PR, Kawasaki ES, Yu L-Y \& Bancroft FC 1981 Thyroid or glucocorticoid hormone induces pre-growth-hormone mRNA and its probable nuclear precursor in rat pituitary cells. Proceedings of the National Academy of Sciences of the USA 78 2230-2234.

Döhler DK \& Wuttke W 1974 Serum LH, FSH, prolactin and progesterone from birth to puberty in female and male rats. Endocrinology 94 1003-1008.

Dollé P, Castrillo JL, Thiell LE, Deerinck T, Ellisman M \& Karin M 1990 Expression of GHR-1 protein in mouse pituitaries correlates both temporally and spatially with the onset of growth hormone gene activity. Cell 60 809-820.

Ellerkmann E, Nagy GM \& Frawlery LS 1991 Rapid augmentation of prolactin cell number and secretory capacity by an estrogen-induced factor released from the neurointermediate lobe. Endocrinology 129 838-842.

Gabriel SM, Roncancio JR \& Ruiz NS 1992 Growth hormone pulsatility and endocrine milieu during sexual maturation in male and female rats. Neuroendocrinology $\mathbf{5 6} 619-628$.

González-Parra S, Chowen JA, García Segura LM \& Argente J $1996 a$ Ontogeny of pituitary transcription factor-1 (Pit-1), growth hormone $(\mathrm{GH})$ and prolactin (PRL) mRNA levels in male and female rats and the differential expression of Pit-1 in lactotrophs and somatotrophs. Journal of Neuroendocrinology 8 211-225.

González-Parra S, Chowen JA, García-Segura LM \& Argente J 1996 b in vivo and in vitro regulation of pituitary transcription factor-1 (Pit-1) by changes in the hormone environment. Neuroendocrinology 63 3-15.

González-Parra S, Argente J, García-Segura LM \& Chowen JA 1998 Cellular composition of the adult rat anterior pituitary is influenced by the neonatal sex steroid environment. Neuroendocrinology $\mathbf{6 8}$ 152-162.

Goth MI, Lyons CE Jr, Ellwood MR, Barrett JR \& Thorner MO 1996 Chronic estrogen treatment in male rats reveals mammosomatotropes and allows inhibition of prolactin secretion by somatostatin. Endocrinology 137 274-280.

Gubbins EJ, Maurer RA, Hartley JL \& Donelson JE 1979 Construction and analysis of recombinant DNAs containing a structural gene for rat prolactin. Nucleic Acids Research 6 915-930.

Gubbins EJ, Maurer RA, Lagrimini M, Erwin CR \& Donelson JE 1980 Structure of the rat prolactin gene. Journal of Biological Chemistry 255 8655-8862.

Harpold MM, Dobner PR, Evans RM \& Bancroft FC 1978 Construction and identification by positive hybridization-translation of a bacterial plasmid containing a rat growth hormone structural gene sequence. Nucleic Acids Research 5 3037-2053.

Ho KY, Leong DA, Sinha YN, Johnson ML, Evans WS \& Thorner MO 1986 Sex-related differences in GH secretion in the rat using the reverse hemolytic plaque assay. American Journal of Physiology 250 E650-E654. 
Ho KY, Thorner MO, Dreig RJ Jr, Lau SK, Sinha YN, Johnson ML, Leong DA \& Evans WS 1988 Effects of gonadal steroids on somatotroph function in the rat: analysis by the reverse hemolytic plaque assay. Endocrinology 123 1405-1411.

Hoeffler JP \& Frawley LS 1986 Capacity of individual somatotropes to release growth hormone varies according to sex: analysis by reverse hemolytic plaque assay. Endocrinology 119 1037-1041.

Hoeffler JP \& Frawley LS 1987 Hypothalamic factors differentially affect the proportions of cells that secrete growth hormone or prolactin. Endocrinology 120 791-795.

Jansson J-O, Edén S \& Isaksson O 1985 Sexual dimorphism in the control of growth hormone secretion. Endocrine Reviews 6 $128-150$.

Jansson J-O \& Frohman LA 1987a Differential effects of neonatal and adult androgen exposure of the growth hormone secretory pattern in male rats. Endocrinology 120 1551-1557.

Jansson J-O \& Frohman LA $1987 b$ Inhibitory effect of the ovaries on neonatal androgen imprinting of growth hormone secretion in female rats. Endocrinology 121 1417-1423.

Keefer D \& Holdeegger 1985 The ontogeny of estrogen receptors: brain and pituitary. Brain Research 351 129-142.

Lam KS, Lee MF, Tam SP \& Srivastava G 1996 Gene expression of the receptor for growth-hormone-releasing hormone is physiologically regulated by glucocorticoids and estrogen. Neuroendocrinology 63 475-480.

Li S, Crenshaw EB, Rawsom EJ, Simmons DM, Swanson LW \& Rosenfeld MG 1991 Dwarf locus mutants lacking three pituitary cell types results from mutations in the POU-domain gene pit-1. Nature 347 528-533.

Lin C, Lin SC, Chang CP \& Rosenfeld MG 1992 Pit-1-dependent expression of the receptor for growth hormone releasing factor mediates pituitary cell growth. Nature 360 765-767.

Matsumoto A 1991 Synaptogenic action of sex steroids in developing and adult neuroendocrine brain. Psychoneuroendocrinology 16 25-40.

Matsumoto A \& Arai Y 1976 Effect of estrogen on early postnatal development of synaptic formation in the hypothalamic arcuate nucleus of female rats. Neuroscience Letters 2 76-83.

Matsumoto AM, Paulsen CA, Hopper BR, Rebar RW \& Bremner WJ 1983 Human chorionic gonadotropin and testicular function: stimulation of testosterone, testosterone precursors, and sperm production despite high estradiol levels. Journal of Clinical Endocrinology and Metabolism 56 720-725.

Murray HE \& Gilles GE 1993 Investigation of the ontogenetic patterns of rat hypothalamic dopaminergic neurone morphology and function in vitro. Journal of Endocrinology 139 403-414.

Oishi Y, Okuda M, Takahashi H, Fujii T \& Morii S 1993 Cellular proliferation in the anterior pituitary gland of normal adult rats: influences of sex, estrous cycle and circadian change. Anatomical Record 235 111-120.

Pérez RL, Machiavelli GA, Romano MI \& Burdman JA 1986 Prolactin release, oestrogens and proliferation of prolactin-secreting cells in the anterior pituitary gland of adult male rats. Journal of Endocrinology 108 399-403.
Reznikov AG \& Nosenko ND 1995 Catecholamines in steroiddependent brain development. Journal of Steroid Biochemistry and Molecular Biology 53 349-353.

Scully KM, Gleiberman AS, Lindzey J, Lubahn DB, Dorach KS \& Rosenfeld MG 1997 Role of estrogen receptor-a in the anterior pituitary gland. Molecular Endocrinology 11 674-681.

Shiino M, Ishikawa H \& Rennels EG 1977 In vitro and in vivo studies on cytodifferentiation of pituitary clonal cells derived from the epithelium of Rathke's Pouch. Cell and Tissue Research 181 473-485.

Shull JD, Walent JH \& Gorski J 1987 Estradiol stimulates prolactin gene transcription in primary cultures of rat anterior pituitary cells. Journal of Steroid Biochemistry and Molecular Biology 26 451-456.

Simmons DM, Voss JW, Ingraham HA, Holloway JM, Broide RS, Rosenfeld MG \& Swanson LW 1990 Pituitary cell phenotypes involve cell-specific Pit-1 mRNA translation and synergistic interactions with other classes of transcription factors. Genes and Development 4 695-711.

Smets G, Velkeniers B, Herregodt S, Van Haelst L, Gepts W \& Hooghe Peters EL 1989 Ontogeny of hormone-secreting cells of the rat pituitary gland: an immunocytochemical study on dissociated cells. Histochemical Journal 21 337-342.

Steiner RA Bremner WJ \& Clifton DK 1982 Regulation of luteinizing hormone pulse frequency and amplitude by testosterone in the adult male rat. Endocrinology 111 2055-2061.

Takahashi S \& Kawashima S 1982 Age-related changes in prolactin cell percentage and serum prolactin levels in intact and neonatally gonadectomized male and female rats. Acta Anatomica 113 211-217.

Tong Y, Zhao H, Labrie F \& Pelletier G 1989 Ontogeny of prolactin mRNA in the rat pituitary gland as evaluated by in situ hybridization. Molecular and Cellular Endocrinology 67 11-16.

Van Bael A, Seuntjens E, Proesmans M \& Denef C 1998 Presence of gonadotropin-releasing hormone (GnRH) mRNA in Rathke's pouch and effect of the GnRH-antagonist ORG 30276 on lactotroph development in vitro. Journal of Neuroendocrinology 10 437-445.

Waterman M, Adler S, Nelson C, Greene GL, Evans RM \& Rosenfeld MG 1988 A single domain of the estrogen receptor confers DNA binding and transcriptional activation of the rat prolactin gene. Molecular Endocrinology 2 14-21.

Wilson ME, Price RH Jr \& Handa RJ 1998 Estrogen receptor-beta messenger ribonucleic acid expression in the pituitary gland. Endocrinology 139 5151-5156.

Zeitler P, Argente J, Chowen-Breed JA, Clifton DK \& Steiner RA 1992 Growth hormone-releasing hormone messenger ribonucleic acid in the hypothalamus of the adult male rat is increased by testosterone. Endocrinology 127 1362-1368.

Received 21 April 1999

Revised manuscript received 13 September 1999 Accepted 14 October 1999 